\title{
Reserkch Aтticle: Personal and economic characteristics of Bt cotton farmers
}

Article Chronicle: Received :

18.12.2017;

Revised :

09.01.2018;

Accepted :

25.01.2018

\section{Author for correspondence :}

\section{A.S. Shridevi} Department of Agricultural Extension Education, University of Agricultural Sciences, Dharwad (Karnataka) India

Email : shridevi. sankaratti@gmail.com

See end of the article for authors' affiliations

\section{A.S. Shridevi and S.V. Halakatti}

SUMMARY : Cotton is a major commercial crop in India, but has substantial problems particularly from extensive pest damage and poor yields. Bt cotton offers a promising solution to these serious problem. It may prove beneficial to know socio-economic characteristics of the Bt cotton cultivators as well as their attitude towards Bt cotton. Generally, it is found that all the farmers residing in the same community do not adopt improved agricultural technology to the same extent. This may be because of several reasons such as personal, economic characters which are related to the adoption of improved agricultural practices. Factors which affect these phenomena are age, education, size of family, size of landholding, annual family income. The results of the study revealed, majority of the respondents was middle aged and more number of farmers had studied upto high school, nearly three fourth of farmers having nuclear family. Majority of the Bt cotton farmers had medium farming experience in Bt cotton with small landholdings. Majority of the Bt cotton farmers belonged to medium annual income.

How to cite this article : Shridevi, A.S. and Halakatti, S.V. (2018). Personal and economic characteristics of Bt cotton farmers. Agric. Update, 13(1): 97-100; DOI : 10.15740/HAS/AU/13.1/97-100.
KeY WoRDS:

Land holding, Annual income, Bt cotton 